\title{
The Prevalence and Prognostic Impacts of Nucleophosmin Mutations in Adult Patients with De Novo Acute Myeloid Leukemia
}

\author{
Naglaa Mostafa Hassan ${ }^{1}$, Noha El-Sayed ${ }^{2 *}$ (D), Khaled Aboul-Enein ${ }^{1}$ (D), Lamyaa Nabeeh Al-Fadally ${ }^{1}$, Reem Nabil ${ }^{1}$ (D) \\ ${ }^{1}$ Department of Clinical Pathology, National Cancer Institute, Cairo University, Giza, Egypt; ${ }^{2}$ Department of Microbial \\ Biotechnology, Genetic Engineering and Biotechnology Division, National Research Centre, Dokki, Giza, Egypt
}

Abstract

Edited by: Slavica Hristomanova-Mitkovska Citation: Hassan NM, El-Sayed N, Aboul-Enein K, Al-Fadally LN, Nabil R. The Prevalence and Prognostic Impacts of Nucleophosmin Mutations in Adult Patients with De Novo Acute Myeloid Leukemia. Open Access Maced Med Sci. 2021 Aug 31; 9(A):632-638. https://doi.org/10.3889/oamjms.2021.617 words: Acute myeloid leukemia; Nucleophosmin; Mutation; Real-time polymerase chain reaction orrespondence: Noha ElSayed lbah ch, Departmen of Microbial Biotechnology, Genetic Engineering an Giza, Egypt. E-mail: nohaelsayed855@gmail.com Received: 11-Apr-202 Revised: 30-Jul-202 Accepted: 21-Aug-202 Copyright: ๑ 2021 Naglaa Mostafa Hassan, Noha El-Sayed, Khaled Aboul-Enein,
Lamyaa Nabeeh Al-Fadally, Reem Nabi Funding: This research did not receive any financial Competing Interests: The authors have declared that not competing interests exist Open Access: This is an open-access article distributed
under the terms of the Creative Commons AtributionNonCommercial 4.0 International License (CC BY-NC 4.0)

\section{Introduction}

Acute myeloid leukemia (AML) is known as cancer of the blood and bone marrow (BM) and is regarded as the commonest acute leukemia in adult patients [1]. The disease has a characteristic heterogeneous pattern as it infiltrates marrow BM and other relevant tissues by proliferative, clonal leukemic cells that are abnormally differentiated and possess poor morphological structures, immunophenotype, cytochemistry, cytogenetics, in addition to other molecular abnormalities. It may result from gene mutation or overexpression [2], [3], [4].

Essential cell processes as controlling the duplication of the centrosomes, ribosome biosynthesis and export, protein synthesis and transportation, programming nucleosome and histone, in addition to cellular proliferation, regulation of the genome stability, and DNA amendment is done by nucleophosmin (NPM) which is also known as nucleolar protein NO38, nucleolar phosphoprotein B23, or numatrin by interacting with the $\mathrm{p} 53$ and alternative reading frame tumor suppressors [5], [6]. Mutations in the NPM1 gene can cause various NPM1 mutant products that can lead to serious leukemoid reactions as these are basically found in the cytoplasm of the leukemic cells [7]. Various mutations have been discovered concerning the NPM1 gene with the commonest one known as NPM1 type A mutation (NPM1-mA) which is attributable to $70 \%$ to $80 \%$ of the cases with mutations. In the same context, in $5-10 \%$ of NPM1 mutations-induced AML, other types of mutations as type $B$ and type $D$ could be also detected [8].

The clinical significance of NPM1-mutationsrelated $A M L$ is that extramedullary involvement has been associated with higher proportions of patients in these groups. Such involvement is responsible for many clinical characteristics as lymphadenopathy, gingival hyperplasia, and the presence of myeloid sarcoma [8], [9]. Leukemic infiltration of the skin has been also associated with kinds of mutations which can be referred to as leukemia cutis [10]. Although data obtained from previous studies suggested that such clinical features mainly occur secondary to matrix metalloproteases up-regulation [11], no exact mechanisms have fully explained the phenomenon. Although many studies have been published in this 
field, the outcomes regarding the prognostic values and prevalence are hugely variable based on the studied population. Consequently, in this study, we aim to investigate the NPM mutations and their prognostic impacts in patients that were recently diagnosed with AML.

\section{Materials and Methods}

\section{Study population}

We recruited 89 patients that had de novo AML and were located in the 18-77 age range. They were 52 males (58.4\%) and 37 females (41.6\%). All these patients presented to the medical oncology clinics, National Cancer Institute (NCI), Cairo University, during the period from August 2016 to December 2018. Approval from the institutional review board (IRB) was also obtained (MD2010013006.3, Issue date: March 3, 2013) before conducting this study. During treatment, patients' response to treatment was assessed clinically and by BM examination at days 14 and 28 . The response is categorized as complete remission (CR), partial response, or refractory to treatment. CR was defined following the standard criteria by Döhner et al. [12] which required an absolute neutrophil count of $1.5 \times 10^{9} / \mathrm{L}$, platelet count of $100 \times 10^{9} / \mathrm{L}$ or more, no blasts in peripheral blood (PB), BM cellularity of more than $20 \%$, no Auer rods, $<5 \%$ BM blasts and no extramedullary leukemia. Disease-free survival (DFS) for our patients was measured from the date of $C R$ to the date of relapse or death from any cause.

\section{Total cellular RNA extraction from human}

\section{$B M$}

After obtaining the patient's consent, total RNA was extracted from the BM of all the study groups using QIAamp RNA blood Mini Kit (Qiagen) according to the manufacturer's instructions. Quantitation and purity assessment for RNA samples were done using the Nano Drop ${ }^{\circledR}$ (ND)-1000 spectrophotometer (Nano Drop Technologies, Inc. Wilmington, USA).

\section{Real-time quantitative polymerase chain reaction (RT-qPCR)}

Conversion of RNA to cDNA was done by using the QuantiTect Reverse Transcription Kit (QIAGEN). A $10 \mu \mathrm{l}$ of $2 \times$ RT master mix was pipetted into each tube. The volume of the RNA sample was adjusted according to the concentration of RNA in the sample to make the concentration of cDNA $50 \mathrm{ng} / \mu \mathrm{l}$ and was then completed by nuclease-free $\mathrm{H}_{2} \mathrm{O}$ until the total volume per reaction reached $20 \mu \mathrm{l}$. Thermal cycling conditions for optimization of reverse transcription kits were as follows: $25^{\circ} \mathrm{C}$ for $10 \mathrm{~min}, 37^{\circ} \mathrm{C}$ for $120 \mathrm{~min}, 85^{\circ} \mathrm{C}$ for 5 s [13], [14].

Amplification of cDNA to detect NPM mutation type A expression by using the ipsogen NPM1 mutA MutaQuant Kit (cat no. 67751) allowed the quantification of NPM1 mutA transcripts by RT-qPCR, depending on the already-characterized NPM1 genotype of the sample to be analyzed. The kit included primers and probes spanning NPM1 exons 11 and 12 exclusively to detect NPM1 mutations in cDNA. Control primers and probes that were included to detect plasmids specific for ABL and NPM1 mutA to normalize NPM1 copy numbers in samples. qPCR allowed for accurate quantification of PCR products during the exponential phase of the PCR amplification process. qPCR data could be rapidly obtained, without post-PCR processing, by $R T$ detection of fluorescent signals during and/or after PCR cycling [15].

\section{Statistical analysis}

The study data have been analyzed by using $\mathrm{IBM}^{\odot}$ SPSS $^{\odot}$ Statistics version $22\left(\right.$ IBM $^{\odot}$ Corp., Armonk, NY, USA). Data expression and presentation were done based on the nature of the raw data for the study variables as follows: we presented the numerical ones in mean (standard deviation) or median (range). On the other hand, we presented qualitative data as frequency (percentage). Besides, we also used Chi-square or Fisher's exact tests to interpret and examine the correlation between the qualitative variables of this study. Whenever data were not normally distributed, we, depending on the Mann-Whitney test which is a non-parametric t-test, initiated a comparison between two groups to find which variables were significant between the two groups where a $p<0.05$ was marked significant. It should also be noted that all of the conducted tests were done on a two-tailed basis.

\section{Results}

\section{Patients' characteristics}

We have included $89 \mathrm{AML}$ patients in our study. The median age for these patients was 43 years old (range: 15-77). Hepatomegaly and splenomegaly were encountered in $13(14.6 \%)$ and $13(14.6 \%)$ patients, respectively, while lymphadenopathy was found in $20(22.5 \%)$ patients. Regarding the hematological findings in our patients, the median WBCs, and platelet counts were $15.3 \times 10^{9} / \mathrm{L}\left(0.10-358.6 \times 10^{9} / \mathrm{L}\right)$, and $33 \times 10^{9} / \mathrm{L}\left(4-290 \times 10^{9} / \mathrm{L}\right)$, respectively, while the median $\mathrm{Hb}$ level was 7.8 (3.5-14) g/dL. Besides, BM was hypercellular in $82 \%$, normocellular in $15.7 \%$, and 
hypocellular in $2.2 \%$ of our patients. The median of $\mathrm{PB}$ blasts percentages was $49 \%$ (1-98\%), while a median of $73 \%(20-97 \%)$ was noticed within the BM. As for the immunophenotyping, all our cases were positive for CD13 and CD33 while CD34 was detected in 51 cases $(57.3 \%)$, and $88(98.9 \%)$ cases were positive for MPO. In the same context, 28 cases were positive for monocytic markers CD14, CD4, CD64 (31.5\%), and only one case was positive for megakaryocytic markers CD41, CD61 (1.1\%). According to the World Health Organization (WHO) classification recurrent genetic abnormalities were detected in $30.3 \%$ of our AML patients. Such abnormalities are presented in Table 1. Regarding patients' response to treatment, $58 \%$ of patients died befor $28^{\text {th }}$ day of treatment while $33 \%$ achieved CR after $28^{\text {th }}$ day of starting chemotherapy and $9 \%$ had a refractory pattern.

Table 1: Molecular and cytogenetic analysis findings and classification of AML cases according to the FAB and WHO classification

\begin{tabular}{|c|c|c|}
\hline Genetics and classification & $\mathrm{n}=89$ & Percent \\
\hline \multicolumn{3}{|l|}{ FLT3 mutation } \\
\hline Wild ITD Wild TDK & 37 & 41.6 \\
\hline Mutant ITD Wild TDK & 28 & 31.5 \\
\hline Wild ITD mutant TDK & 20 & 22.5 \\
\hline \multicolumn{3}{|l|}{ NPM1 mutation } \\
\hline Wild & 56 & 62.9 \\
\hline Mutant & 33 & 37.1 \\
\hline \multicolumn{3}{|l|}{ Conventional cytogenetic ${ }^{*}$} \\
\hline Normal karyotype & 39 & 53.5 \\
\hline Abnormal Karyotype & 34 & 38.2 \\
\hline \multicolumn{3}{|l|}{ FAB classification } \\
\hline AML without differentiation (M0) & 1 & 1.1 \\
\hline AML without maturation (M1) & 14 & 15.7 \\
\hline AML with maturation (M2) & 31 & 34.8 \\
\hline Acute promyelocytic leukemia (M3) & 14 & 15.7 \\
\hline Acute myelomonocytic leukemia (M4) & 22 & 24.7 \\
\hline Acute monoblastic leukemia (M5) & 6 & 6.7 \\
\hline Acute megakaryocytic leukemia (M7) & 1 & 1.1 \\
\hline \multicolumn{3}{|l|}{ WHO classification } \\
\hline \multicolumn{3}{|l|}{ AML with recurrent genetic abnormalities } \\
\hline AML with $\mathrm{t}(8,21)(\mathrm{q} 22 ; \mathrm{q} 22) ; \mathrm{RUNX1-RUNX1T1}$ & 7 & 7.9 \\
\hline AML with $\mathrm{t}(15 ; 17)(\mathrm{q} 22 ; \mathrm{q} 12) ; \mathrm{PML}-\mathrm{RARA}$ & 14 & 15.7 \\
\hline AML with inv(16)(p13.1q22); CBFB-MYH11 & 6 & 6.7 \\
\hline \multicolumn{3}{|l|}{ AML not otherwise specified } \\
\hline AML without differentiation & 1 & 1.1 \\
\hline AML without maturation & 14 & 15.7 \\
\hline AML with maturation & 25 & 28.1 \\
\hline Acute myelomonocytic leukemia & 15 & 16.9 \\
\hline Acute monoblastic leukemia & 6 & 6.7 \\
\hline Acute megakaryocytic leukemia & 1 & 1.1 \\
\hline \multicolumn{3}{|l|}{ Response to treatment } \\
\hline Early dead & 52 & 58 \\
\hline $\mathrm{CR}$ & 29 & 33 \\
\hline Refractory & 8 & 9 \\
\hline Refractory & 8 & 9 \\
\hline
\end{tabular}

tandem duplication, TDK: Tyrosine kinase domain, ${ }^{*} n=73$ AML cases.

\section{Genetic analysis and classification}

Within our AML patients, normal karyotye was found in $43.8 \%$ while $38.2 \%$ had abnormal karyptype. Gene mutation status showed that $41.6 \%$ of cases were Wild internal tandem duplication (ITD) wild tyrosine kinase domain (TDK), $31.5 \%$ were mutant ITD wild TDK while $22.5 \%$ were wild ITD mutant TDK. All the relevant genetic profiles are presented in Table 1. NPM1 gene mutation was detected in (33/89) $37.1 \%$ of our patients by conventional PCR technique and agarose gel electrophoresis. Among mutant NPM1 gene, we found NPM1 mutation A mRNA transcripts expression in $6 / 33(18 \%)$ patients ranged between $140-2060 \%$ $\mathrm{NCN}(\mathrm{NCN}=[$ mutACN/ABLCN] $\times 100)$ which was less than the least standard sample (not within the standard curve) (Table 2).

Table 2: Expression of NPM1 mutation A mRNA transcripts by quantitative RT-PCR

\begin{tabular}{ll}
\hline Case & NCN\% \\
\hline 1 & 139.8 \\
2 & 744.06 \\
3 & 835.3 \\
4 & 1450.1 \\
5 & 1623.64 \\
6 & 2159.5 \\
\hline NPM1: Nucleophosmin 1, RT-PCR: Real-time polymerase chain reaction.
\end{tabular}

\section{NPM1 mutations and the clinical and molecular features}

Regarding the clinical significance, no significant differences were noticed between our patients based on their NPM1 gene mutation status (wild and mutant) in terms of sex, hepatomegaly, and splenomegaly ( $p=0.375,0.429$, and 0.429, respectively). On the other hand, lymphadenopathy was the only significant factor $(p=0.023)$. We found 9/33 (27\%) patients with NPM1 mutation had recrrent cytogenetic abnormality $(2,5$ and 2 patients with $\mathrm{t}(8 ; 21)$, $\mathrm{t}(15 ; 17)$ and inv16 respectively). Besides, no statistical significance was estimated regarding the laboratory data or achieving CR between the two groups (Table 3). The previous outcomes were also compared based on the presence of NPM1 mutation A status as patients were divided into NPM1-mutant non-A ( $\mathrm{n}=27$ ), and NPM1mutant $A(n=6)$. No statistical significance was found between the two groups in any of the studied outcomes as sex, clinical, and laboratory data (Table 4). Besides, among the patients with muta A type mutations $(n=6)$, we found that only one patient $(16.7 \%)$ was positive for $\mathrm{t}(8 ; 21)$, another one $(16.7 \%)$ with normal cytogenetics while neither of these patients were positive for inv. 16 . No statistical significance was found between patietns with NPM1-mutant non-A and NPM1-mutant A in any of these variables. Further detalis are presented in Table 4. Regarding the treatment outcomes, dead or refractory patients accounted for $70 \%$ and $83.3 \%$ while patients that achieved CR accounted for $30 \%$ and $16.7 \%$ among patients within the NPM1-mutant non-A and NPM1-mutant A groups, respectively. However, we found no statistical significance between the two groups regarding this outcomes $(p=0.487)$.

\section{Discussion}

Genetic mutations possess crucial roles in the development, prognosis, and pathogenesis of AML. However, it is not necessary to detect such mutations in all AML patients [1]. NPM1 gene mutations frequently 
Table 3: Comparing patients' characteristics according to their NPM1 gene mutation results

\begin{tabular}{|c|c|c|c|}
\hline \multirow[t]{2}{*}{ Patients' characteristics } & \multicolumn{2}{|l|}{ NPM (\%) } & \multirow[t]{2}{*}{$p$-value } \\
\hline & Wild $(n=56)$ & Mutant $(n=33)$ & \\
\hline \multicolumn{4}{|l|}{ Sex } \\
\hline Male & $35(62.5)$ & $17(51.5)$ & \multirow[t]{2}{*}{0.375} \\
\hline Female & $21(37.5)$ & $16(48.5)$ & \\
\hline \multicolumn{4}{|l|}{ Hepatomegaly } \\
\hline Negative & 47 (83.9) & $29(87.9)$ & \multirow[t]{2}{*}{0.429} \\
\hline Positive & $9(16.1)$ & $4(12.1)$ & \\
\hline \multicolumn{4}{|l|}{ Splenomegaly } \\
\hline Negative & $47(83.9)$ & 29 (87.9) & \multirow{2}{*}{0.429} \\
\hline Positive & $9(16.1)$ & $4(12.1)$ & \\
\hline \multicolumn{4}{|l|}{ Lymphadenopathy } \\
\hline Negative & 39 (70.9) & $30(90.9)$ & \multirow{2}{*}{$0.023^{*}$} \\
\hline Positive & $16(29.1)$ & $3(9.1)$ & \\
\hline \multicolumn{4}{|l|}{ BM Cellularity } \\
\hline Hypercellular & $43(76.8)$ & $30(90.9)$ & \multirow[t]{3}{*}{0.207} \\
\hline Normocellular & $11(19.6)$ & $3(9.1)$ & \\
\hline Hypocellular & $2(3.6)$ & 0 & \\
\hline \multicolumn{4}{|l|}{ FAB } \\
\hline AML-M0 & 0 & $1(3)$ & \multirow[t]{7}{*}{0.235} \\
\hline AML-M1 & $8(14.3)$ & $6(18.2)$ & \\
\hline AML-M2 & $19(33.9)$ & $12(36.4)$ & \\
\hline AML-M3 & $9(16.1)$ & $5(15.2)$ & \\
\hline AML-M4 & $15(26.8)$ & $7(21.2)$ & \\
\hline AML-M5 & $4(7.1)$ & $2(6)$ & \\
\hline AML-M7 & $1(1.8)$ & 0 & \\
\hline \multicolumn{4}{|l|}{ CD34 } \\
\hline Negative & $25(44.6)$ & $13(39.4)$ & \multirow[t]{2}{*}{0.663} \\
\hline Positive & $31(55.4)$ & $20(60.6)$ & \\
\hline \multicolumn{4}{|l|}{ MPO } \\
\hline Negative & $1(1.8)$ & 0 & \multirow[t]{2}{*}{1} \\
\hline Positive & $55(98.2)$ & $33(100)$ & \\
\hline \multicolumn{4}{|l|}{ Monocyte markers } \\
\hline Negative & $37(66.1)$ & $24(72.7)$ & 0.638 \\
\hline Positive & $19(33.9)$ & $9(27.3)$ & \\
\hline Flt3 & & & \\
\hline Wild ITD wild TDK & $21(38.9)$ & $16(51.6)$ & 0.392 \\
\hline mutant ITD wild TDK & $18(33.3)$ & $10(32.3)$ & \\
\hline Wild ITD mutant TDK & $15(27.8)$ & $5(16.1)$ & \\
\hline $\mathrm{t}(8.21)$ & & & \\
\hline Negative & $51(91.1)$ & 31 (93.9) & 1 \\
\hline Positive & $5(8.9)$ & $2(6.1)$ & \\
\hline PML RARA & & & \\
\hline Negative & $47(83.9)$ & $28(84.8)$ & 1 \\
\hline Positive & $9(16.1)$ & $5(15.2)$ & \\
\hline Inv. 16 & & & \\
\hline Negative & $52(92.9)$ & 31 (93.9) & 0.607 \\
\hline Positive & $4(7.1)$ & $2(6.1)$ & \\
\hline Cytogenetics & & & \\
\hline Normal & $24(53.3)$ & $15(53.6)$ & 1 \\
\hline Abnormal & $21(46.7)$ & $13(46.4)$ & \\
\hline Response to treatment & & & \\
\hline Early dead & $33(59)$ & $19(58)$ & 0.267 \\
\hline CR & $20(36)$ & $9(27)$ & \\
\hline Refractory & $3(5)$ & $5(15)$ & \\
\hline
\end{tabular}

occur in hematopoietic tumors as it plays a major role in various cellular processes as gene fusion which result from chromosome translocation [16]. NPM1 genetic mutations lead to harmful cytoplasmic localization of nucleoplasmin proteins [7]. Although such mutations have been reported to be frequently associated with the development of AML, no aberrant unusual keratotyping has been associated [7]. We analyzed the level of expression of NPM mutation A mRNA using RT-PCR studied on 89 patients that were newly diagnosed with adult $\mathrm{AML}$ in the medical oncology department at the $\mathrm{NCl}$ to gain insight into its correlated clinical characteristics in AML and different laboratory findings and its impact on prognosis.

We found that the prevalence of NPM1 mutations in our population was $37.1 \%$ in our AML patients which is similar to the results by lvey et al. [17], which found NPM1 gene mutation in $30 \%$ to $35 \%$ of his studied AML patients, Thiede et al. [18] reported a rate of $27.47 \%$ in their patients and with Mahmood
Table 4: Comparing patients' characteristics according to the type of NPM1 gene mutations

\begin{tabular}{|c|c|c|c|}
\hline \multirow[t]{2}{*}{ Patients' characteristics } & \multicolumn{2}{|l|}{ NPM (\%) } & \multirow[t]{2}{*}{ p-value } \\
\hline & $\operatorname{Non} A(n=27)$ & Muta $A(n=6)$ & \\
\hline \multicolumn{4}{|l|}{ Sex } \\
\hline Male & $14(51.9)$ & $3(50)$ & \multirow[t]{2}{*}{1} \\
\hline Female & $13(48.1)$ & $3(50)$ & \\
\hline \multicolumn{4}{|l|}{ Hepatomegaly } \\
\hline Negative & $24(88.9)$ & $5(83.3)$ & \multirow[t]{2}{*}{1} \\
\hline Positive & $3(11.1)$ & $1(16.7)$ & \\
\hline \multicolumn{4}{|l|}{ Splenomegaly } \\
\hline Negative & $24(88.9)$ & $5(83.3)$ & \multirow[t]{2}{*}{1} \\
\hline Positive & $3(11.1)$ & $1(16.7)$ & \\
\hline \multicolumn{4}{|l|}{ Lymphadenopathy } \\
\hline Negative & $25(92.6)$ & $5(83.3)$ & \multirow[t]{2}{*}{0.464} \\
\hline Positive & $2(7.4)$ & $1(16.7)$ & \\
\hline \multicolumn{4}{|l|}{ BM Cellularity } \\
\hline Hypercellular & 25 (92.6) & $5(83.3)$ & \multirow[t]{2}{*}{0.464} \\
\hline Normocellular & $2(7.4)$ & $1(16.7)$ & \\
\hline \multicolumn{4}{|l|}{ FAB } \\
\hline AML-MO & $1(3.7)$ & 0 & \multirow[t]{7}{*}{0.716} \\
\hline AML-M1 & $6(22.2)$ & 0 & \\
\hline AML-M2 & 9 (33.3) & $3(50)$ & \\
\hline AML-M3 & $4(14.8)$ & $1(16.7)$ & \\
\hline AML-M4 & $5(18.5)$ & $2(33.3)$ & \\
\hline AML-M5 & $2(7.4)$ & 0 & \\
\hline AML-M7 & $1(3.7)$ & 0 & \\
\hline CD13 (positive) & $27(100)$ & $6(100)$ & NA \\
\hline CD33 (positive) & $27(100)$ & $6(100)$ & NA \\
\hline \multicolumn{4}{|l|}{ CD34 } \\
\hline Negative & $12(44.4)$ & $1(16.7)$ & \multirow[t]{2}{*}{0.364} \\
\hline Positive & $15(55.6)$ & $5(83.3)$ & \\
\hline \multicolumn{4}{|l|}{ CD14_CD4_CD64 } \\
\hline Negative & $20(74.1)$ & $4(66.7)$ & \multirow[t]{2}{*}{0.918} \\
\hline Positive & $7(25.9)$ & $2(33.3)$ & \\
\hline CD41_61 (negative) & $27(100)$ & $6(100)$ & NA \\
\hline \multicolumn{4}{|l|}{ Flt3 - } \\
\hline Wild ITD wild TDK & $13(52)$ & $3(50)$ & \multirow[t]{3}{*}{0.381} \\
\hline mutant ITD wild TDK & $7(28)$ & $3(50)$ & \\
\hline Wild ITD mutant TDK & $5(20)$ & 0 & \\
\hline \multicolumn{4}{|l|}{$t(8.21)$} \\
\hline Negative & $26(96.3)$ & $5(83.3)$ & 0.335 \\
\hline Positive & $1(3.7)$ & $1(16.7)$ & \\
\hline PML RARA & & & \\
\hline Negative & $23(85.2)$ & $5(83.3)$ & 1 \\
\hline Positive & $4(14.8)$ & $1(16.7)$ & \\
\hline Inv. 16 & & & \\
\hline Negative & $25(92.6)$ & $6(100)$ & 1 \\
\hline Positive & $2(7.4)$ & 0 & \\
\hline Cytogenetics (normal) & $14(58.3)$ & $1(25)$ & 0.311 \\
\hline Response to treatment & & & \\
\hline Dead/Refractory & $19(70)$ & $5(83.3)$ & 0.487 \\
\hline $\mathrm{CR}$ & $8(30)$ & $1(16.7)$ & \\
\hline
\end{tabular}

et al. [19] who found NPM1 mutation in $26.9 \%$ AML patients. Other studies have also reported similar results [7], [18], [20], [21], [22], [23]. On the other hand, Pazhakh et al. [24] estimated NPM1 mutations in a lower percentage $(17.5 \%)$ of AML patients, and Döhner et al. [25] recorded NPM1 mutations in a higher percentage $(48 \%)$ of normal karyotypic AML patients which was consistent with Kassem et al. [26], and Nafea et al. [27] who found that the mutation was detected in higher percentage ( $45.8 \%$ and $47.9 \%$ respectively). This discrepancy may be due to different populations, different sample sizes, and selection criteria or may be due to different approached techniques.

Regarding the study outcomes, we did not find any significant differences in terms of sex, hepatomegaly, and splenomegaly based on NPM1 mutation results. Only lymphadenopathy occurred significantly more frequently in patients with wild NPM1 genes while other laboratory data were not, as mentioned before. In the same context, Boissel et al. [28] reported that no significant difference between mutant and non-mutant NPM1 groups in terms of $\operatorname{sex}(p=0.375)$ was estimated. On the other hand, Mahmood et al. [19] reported the 
opposite as their study found significance in terms of the female gender, higher hemoglobin level, and platelet counts which were associated with the NPM1 mutation group. Similarly, Falini et al. [8], and Döhner et al. [24] estimated statistical significance, and according to which, they claimed that lymphadenopathy and gingival hyperplasia were associated with NPM1 mutations. These results can be explained by the presence of such mutations in M4 and M5 French-AmericanBritish (FAB) subtypes which are usually associated with lymphadenopathy and gum hyperplasia. However Kassem et al. [26], and Boonthimat et al. [20], reported that no significant clinical outcomes were correlated with the presence of NPM1 genetic mutations.

Falini et al. [29] showed that NPM mutation was more common in M5 (14/23) and M4 (9/20) subtypes while it was absent in $\mathrm{MO}(0 / 2)$ which is inconsistent with our results as we found NPM1 mutation more in M2. In the same context, Döhner et al. [25] and Falini et al. [8] also reported that M4and M5 subtypes were significantly associated with higher proportions of NPM1 mutations as detected in their patients. The same results were also reported by previous studies [18], [26], [27], [30]. On the other hand, Pazhakh et al. [24] estimated that the occurrence of NPM1 mutation was mostly found in M3, M4, M5, and M3V patients. M1 subtype was the commonest (34\%) as reported by Verhaak et al. [22] in their population.

We also found that gene mutations occurred in $53.6 \%$ of our population with normal karyotypes. This rate is variable among previous studies and can be ranging between $40 \%$ and $60 \%$ of $A M L$ patients. Regarding prognosis, we found that among our AML patients with mutant NPM1 genes, $73 \%$ died before day 28 which may be due to old age, secondary infections, and late diagnosis. Therefore, we could not estimate the correlation between the NPM1 mutant gene and the early response to treatment in $A M L$ patients. Mahmood et al. [19] estimated the CR rates in NPM1-mutation AML to be $72 \%$ while the median DFS was 16.1 months. Previous reports also estimated consistent findings [7], [8], [18], [25], [31], [32]. On the contrary, Wang et al. [33] and Boonthimat et al. [20] reported that no association was found between the presence of NPM1 mutations and the prognosis of AML patients.

The prevalence rate of NPM1 mutation A was $18 \%$ of our AML patients with mutant NPM1 genes, and $6.7 \%$ of all our AML patients which is similar to the findings by Falini et al. [30] and much lower than other previous studies [25], [34], [35] which may be attributable to the differences in patients' baseline demographics and inclusion criteria. We did not find any significance regarding the clinical and laboratory features among patients with type A NPM1 mutations. However, NPM1 gene mutation $A$ was higher in some variables as FAB classification M2 (50\%) and
M4 (33\%), despite not being statistically significant. Quan et al. [36], on the other hand, reported that M5 subgroups were associated with higher NPM1 mutation A more than $\mathrm{M} 2$ and $\mathrm{M} 4$.

\section{Conclusion}

The frequency of NPM1 gene mutation was comparable to previous investigations while NPM1 gene mutation A was relatively low among our population. Besides, we could evaluate some relations of NPM1 mutation with initial laboratory prognostic parameters as blood count, BMA findings, FAB classification, karyotyping, and gene mutations. However, we could not evaluate its relation to response to treatment nor survival as many early deaths in our adult AML patients occurred. Consequently, more studies with larger samples are recommended and also to illustrate the frequency of non A mutant NPM1 gene and their prognostic roles.

\section{Ethics Approval}

All eligible individuals agreed to voluntary participation and signed an informed consent form. The study was approved by the research ethics committee of irb, $\mathrm{NCl}$, Cairo University, Approval No. MD2010013006.

\section{Author Contributions}

Participated in research design: Naglaa Mostafa Hassan, Khaled Aboul-Enein. Sample collection and clinical evaluations: Lamyaa Nabeeh Al- Fadally, Reem Nabil. Conducted experiments: Lamyaa Nabeeh Al- Fadally, Reem Nabil, Noha El-Sayed Ibrahim. Analysis of data: Naglaa Mostafa Hassan, Khaled Aboul-Enein. Literature search: Noha El-Sayed Ibrahim, Lamyaa Nabeeh Al- Fadally, Reem Nabil. Wrote or contributed to the writing of the manuscript: Noha El-Sayed Ibrahim, Reem Nabil. revision of the article: Naglaa Mostafa Hassan, Khaled Aboul-Enein. All authors read and approved the final manuscript. 


\section{Availability of Data and Materials}

The authors have ready to send data and the detailed scientific materials if it is useful for readings.

\section{References}

1. Kouchkovsky I, Abdul-Hay M. Acute myeloid leukemia: A comprehensive review and 2016 update. Blood Cancer J. 2016;6(7):e441. https://doi.org/10.1038/bcj.2016.50 PMid:27367478

2. Döhner $\mathrm{H}$, Weisdorf $\mathrm{DJ}$, Bloomfield $\mathrm{CD}$. Acute myeloid leukemia N Engl J Med. 2015;373(12):1136-52. https://doi.org/10.1056/ nejmra1406184

PMid:26376137

3. Gregory TK, Wald D, Chen Y, Vermaat JM, Xiong Y, Tse W. Molecular prognostic markers for adult acute myeloid leukemia with normal cytogenetics. J Hematol Oncol. 2009;2:23. https:// doi.org/10.1186/1756-8722-2-23

PMid:19490647

4. Burnett A, Wetzler M, Löwenberg B. Therapeutic Advances in Acute Myeloid Leukemia. J Clin Oncol. 2011;29(5):487-94. https://doi.org/10.1200/jco.2010.30.1820

PMid:21220605

5. Falini B. Acute myeloid leukemia with mutated nucleophosmin (NPM1): Molecular, pathological, and clinical features. In: Nagarajan L, editor. Acute Myelogenous Leukemia: Genetics, Biology and Therapy. New York: Springer; 2010. p. 149-68. https://doi.org/10.1007/978-0-387-69259-3_9

6. Lindström M. NPM1/B23: A multifunctional chaperone in ribosome biogenesis and chromatin remodeling. Biochem Res Int. 2011;2011:195209. https://doi.org/10.1155/2011/195209

PMid:21152184

7. Falini B, Mecucci C, Tiacci E, Alcalay M, Rosati $R$ Pasqualucci $\mathrm{L}$, et al. Cytoplasmic nucleophosmin in acute myelogenous leukemia with a normal karyotype. N Engl J Med. 2005;352(3):254-66. https://doi.org/10.1056/nejmoa041974 PMid: 15659725

8. FaliniB, Nicoletti I, Martelli MF, Mecucci C. Acute myeloid leukemia carrying cytoplasmic/mutated nucleophosmin (NPMc+ AML) Biologic and clinical features. Blood. 2006;109(3):874-85. https://doi.org/10.1182/blood-2006-07-012252 PMid:17008539

9. Falini B, Lenze D, Hasserjian R, Jaehne D, Soupir C, Liso A, et al. Cytoplasmic mutated nucleophosmin (NPM) defines the molecular status of a significant fraction of myeloid sarcomas. Leukemia. 2007;21(7):1566-70. https://doi.org/10.1038/ sj.leu.2404699 PMid: 17443224

10. Luskin MR, Huen $A O$, Brooks SA, Stewart $C$, Watt $C D$, Morrissette JJ, et al. NPM1 mutation is associated with leukemia cutis in acute myeloid leukemia with monocytic features. Haematologica. 2015;100(10):e412-4. https://doi.org/10.3324/ haematol.2015.129346 PMid:26113416

11. Xian J, Shao H, Chen X, Shuaishuai Z, Quan J, Zou Q, et al. Nucleophosmin mutants promote adhesion, migration and invasion of human leukemia THP-1 cells through MMPs up-regulation via Ras/ERK MAPK signaling. Int J Biol Sci.
2016;12(2):144-55. https://doi.org/10.7150/ijbs.13382 PMid:26884713

12. Döhner H, Estey EH, Amadori $\mathrm{S}$, Appelbaum FR, Büchner $T$, Burnett AK, et al. Diagnosis and management of acute myeloid leukemia in adults: Recommendations from an international expert panel, on behalf of the European LeukemiaNet. Blood. 2010;115(3):453-74. https://doi.org/10.1182/ blood-2009-07-235358

PMid:19880497

13. Sabry D, Mostafa A, Mekawey D, Altaib Z, Shamaa A, Hany A, et al. An experimental model: Intrauterine adhesion versus subendometrial fibrosis. Biomed Res. 2018;29(17):3311-8. https://doi.org/10.4066/biomedicalresearch.29-18-849

14. Sanders R, Mason DJ, Foy CA, Huggett JF. Evaluation of digital PCR for absolute RNA quantification. PLoS One. 2013;8(9):e75296. https://doi.org/10.1371/journal. pone.0075296

PMid:24073259

15. Kumar D, Mehta A, Panigrahi MK, Nath S, Saikia KK. NPM1 mutation analysis in acute myeloid leukemia: Comparison of three techniques-sanger sequencing, pyrosequencing, and real-time polymerase chain reaction. Turk J Haematol. 2018;35(1):49-53. https://doi.org/10.4274/tjh.2017.0095 PMid:29129825

16. Grisendi S, Bernardi R, Rossi M, Cheng K, KhandkerL, Manova K, et al. Role of nucleophosmin in embryonic development and tumorigenesis. Nature. 2005;437(7055):147-53. https://doi. org/10.1038/nature03915

PMid: 16007073

17. Ivey A, Hills RK, Simpson MA, Jovanovic JV, Gilkes A, Grech A, et al. Assessment of minimal residual disease in standardrisk AML. N Engl J Med. 2016;374(5):422-33. https://doi. org/10.1056/nejmoa1507471

PMid:26789727

18. Thiede C, Koch S, Creutzig E, Steudel C, Illmer T, Schaich M, et al. Prevalence and prognostic impact of NPM1 mutations in 1485 adult patients with acute myeloid leukemia (AML). Blood. 2006;107(10):4011-20. https://doi.org/10.1182/ blood-2005-08-3167

PMid:16455956

19. Mahmood R, Altaf C, Malik HS, Khan SA. Clinico-Haematologic association and prognostic relevance of NPM1 and FLT3ITD mutations in acute Myeloid Leukaemia. Pak J Med Sci. 2019;35(1):23-8. https://doi.org/10.12669/pjms.35.1.285 PMid:30881390

20. Boonthimat C, Thongnoppakhun W, Auewarakul CU. Nucleophosmin mutation in Southeast Asian acute myeloid leukemia: Eight novel variants, FLT3 coexistence and prognostic impact of NPM1/FLT3 mutations. Haematologica. 2008;93(10):1565-9. https://doi.org/10.3324/haematol.12937 PMid:18641025

21. Suzuki T, Kiyoi H, Ozeki K, Tomita A, Yamaji S, Suzuki R, et al Clinical characteristics and prognostic implications of NPM1 mutations in acute myeloid leukemia. Blood. 2005;106(8):285461. https://doi.org/10.1182/blood-2005-04-1733 PMid:15994285

22. Verhaak RG, Goudswaard CS, van Putten W, Bijl MA, Sanders MA, Hugens W, et al. Mutations in nucleophosmin (NPM1) in acute myeloid leukemia (AML): Association with other gene abnormalities and previously established gene expression signatures and their favorable prognostic significance. Blood. 2005;106(12):3747-54. https://doi.org/10.1182/ blood-2005-05-2168 PMid:16109776

23. Chou WC, Tang JL, Lin LI, Yao M, Tsay W, Chen CY, et al 
Nucleophosmin mutations in de novo acute myeloid leukemia: The age-dependent incidences and the stability during disease evolution. Cancer Res. 2006;66(6):3310-6. https://doi. org/10.1158/0008-5472.can-05-4316

PMid:16540685

24. Pazhakh V, Zaker F, Alimoghaddam K, Atashrazm F. Detection of nucleophosmin and FMS-like tyrosine kinase-3 gene mutations in acute myeloid leukemia. Ann Saudi Med. 2011;31(1):45-50. https://doi.org/10.5144/0256-4947.2011.45

PMid:21245599

25. Döhner K, Schlenk RF, Habdank M, Scholl C, Rücker FG, Corbacioglu A, et al. Mutant nucleophosmin (NPM1) predicts favorable prognosis in younger adults with acute myeloid leukemia and normal cytogenetics: Interaction with other gene mutations. Blood. 2005;106(12):3740-6. https://doi.org/10.1182/ blood-2005-05-2164

PMid:16051734

26. Kassem N, Hamid A, Atia T, Baathallah S, Mahmoud $S$, Moemen $\mathrm{E}$, et al. Novel mutations of the nucleophosmin (NPM-1) gene in Egyptian patients with acute myeloid leukemia: A pilot study. J Egypt Natl Canc Inst. 2011;23(2):73-8. https:// doi.org/10.1016/j.jnci.2011.09.003

\section{PMid:22099964}

27. Nafea DA, Rahman MA, Boris D, Pérot C, Laporte JP, Isnard F, et al. Incidence and prognostic value of NPM1 and FLT3 gene mutations in AML with normal karyotype. Open Hematol J. 2011;5:14-20. https://doi.org/10.2174/1874276901105010014

28. Boissel N, Renneville A, Biggio V, Philippe N, Thomas X, Cayuela JM, et al. Prevalence, clinical profile, and prognosis of NPM mutations in AML with normal karyotype. Blood. 2005;106(10):3618-20. https://doi.org/10.1182/ blood-2005-05-2174

PMid: 16046528

29. Falini B, Bolli N, Liso A, Martelli MP, Mannucci R, Pileri S, et al. Altered nucleophosmin transport in acute myeloid leukaemia with mutated NPM1: Molecular basis and clinical implications. Leukemia. 2009;23(10):1731-43. https://doi.org/10.1038/ leu.2009.124

PMid:19516275
30. Falini B, Martelli MP, Bolli N, Sportoletti P, Liso A, Tiacci E, et al. Acute myeloid leukemia with mutated nucleophosmin (NPM1): Is it a distinct entity? Blood. 2011;117(4):1109-20. https://doi. org/10.1182/blood-2010-08-299990 PMid:21030560

31. Shamaa S, Laimon N, Aladle DA, Azmy E, Elghannam DM, Salem DA, et al. Prognostic implications of NPM1 mutations and FLT3 internal tandem duplications in Egyptian patients with cytogenetically normal acute myeloid leukemia. Hematology. 2014;19(1):22-30. $13 y .0000000085$ https://doi.org/10.1179/16078454 PMid:23540998

32. Rau R, Brown P. Nucleophosmin (NPM1) mutations in adult and childhood acute myeloid leukaemia: Towards definition of a new leukaemia entity. Hematol Oncol. 2009;27(4):171-81. https:// doi.org/10.1002/hon.904 PMid:19569254

33. Wang L, Xu WL, Meng HT, Qian WB, Mai WY, Tong HY, et al. FLT3 and NPM1 mutations in Chinese patients with acute myeloid leukemia and normal cytogenetics. J Zhejiang Univ Sci B. 2010;11(10):762-70. https://doi.org/10.1631/jzus.b1000052 PMid:20872983

34. Schnittger S, Kern W, Tschulik C, Weiss T, Dicker F, Falini B, et al. Minimal residual disease levels assessed by NPM1 mutation-specific RQ-PCR provide important prognostic information in AML. Blood. 2009;114(11):2220-31. https://doi. org/10.1182/blood-2009-03-213389

PMid: 19587375

35. Ottone T, Ammatuna E, Lavorgna S, Noguera N, Buccisano $F$ Venditti $A$, et al. An allele-specific RT-PCR assay to detect Type A mutation of the nucleophosmin-1 gene in acute myeloid leukemia. J Mol Diagn. 2008;10(3):212-6. https://doi. org/10.2353/jmoldx.2008.070166

PMid: 18403613

36. Quan J, Gao YJ, Yang ZL, Chen H, Xian JR, Zhang SS, et al. Quantitative detection of circulating nucleophosmin mutations DNA in the plasma of patients with acute myeloid leukemia. Int $\mathrm{J}$ Med Sci. 2015;12(1):17-22. https://doi.org/10.7150/ijms.10144 PMid:25552914 